\title{
RELATION OF H. PYLORI TO GASTRIC CANCER
}

\author{
Keyllane Da Silva Lindoso Duarte; Ethnary Monteiro de Melo*; Lícia Maria Fernandes \\ Rodrigues; Etiane Conceição Silva Machado; Giovanna Maria Pacheco Barroso Maia; Glória \\ Maria Aguiar Brito Lima; Myrella De Jesus Cruz Gomes; Jamilly Rodrigues Lemos; Emanuella \\ Lima Costa Chagas; Sâmia Gisely Pinto Jansen Pereira; Izadora Carneiro Vieira; Keila Soares \\ Moreira; Julianne Souza Prazeres; Maria Isabella Farias de Araujo
}

Department of Medicine, Uniceuma

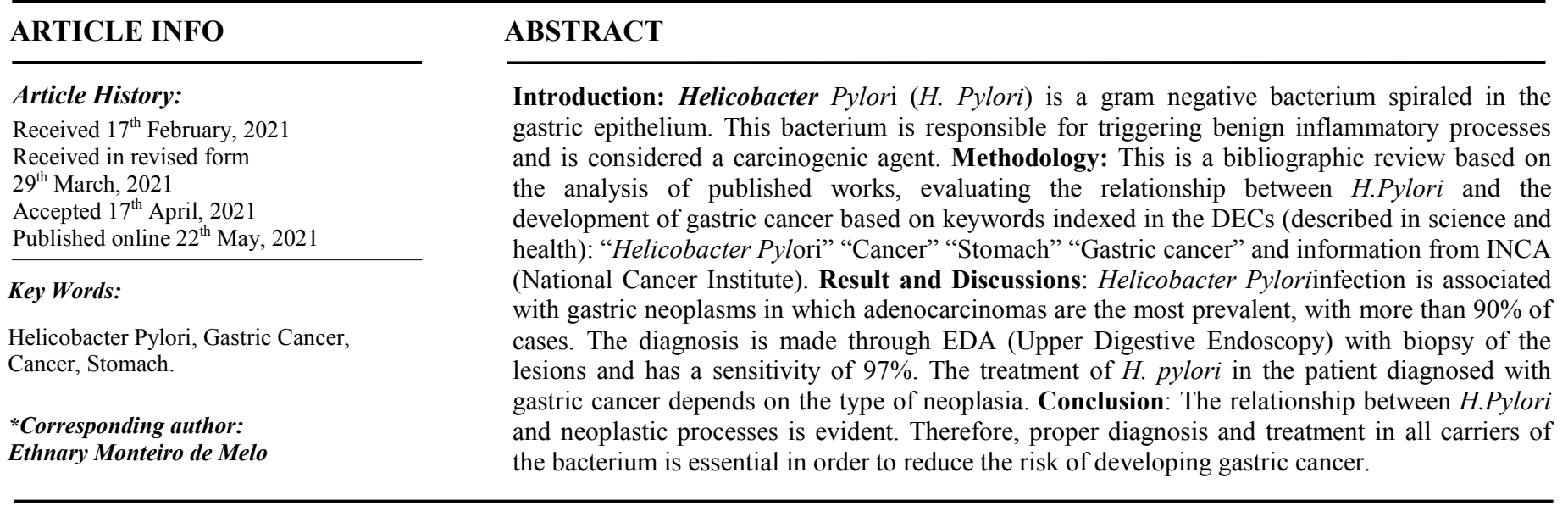

Copyright $\odot$ 2021, Keyllane Da Silva Lindoso Duarte et al. This is an open access article distributed under the Creative Commons Attribution License, which permits unrestricted use, distribution, and reproduction in any medium, provided the original work is properly cited.

Citation: Keyllane Da Silva Lindoso Duarte; Ethnary Monteiro de Melo*; Lícia Maria Fernandes Rodrigues; Etiane Conceição Silva Machado; Giovanna Maria Pacheco Barroso Maia et al. 2021. "Relation of h. pylori to gastric cancer", International Journal of Development Research, 11, (05), $46947-46951$.

\section{INTRODUCTION}

Helicobacter pylori (H.pylori), is a spiral-gram-negative bacterium, described by Warren and Marshall in the early 1980s, according to Zaterka (2016) is responsible for colonizing the gastric mucosa of human beings, triggering an inflammatory process acute (acute gastritis) and, which can progress to chronic inflammation (chronic gastritis), being associated with several other benign gastric pathologies such as duodenitis and gastric and duodenal ulcer, proving to be a triggering factor for pathologies of the gastrointestinal tract. However, it was subsequently associated with malignant gastric disease and is considered a carcinogenic agent for humans (JIMÉNEZ, 2018). Most people infected with H. pylorihave no symptoms, even in the face of an inflammatory process as a response to our immune system. However, prolonged immune responses to gastrointestinal microorganisms can lead to the development of tumors of the gastrointestinal tract, as an example we have MALT lymphoma that occurs in individuals with chronic H. pylori infection. (ABBAS, 2015). People infected with these bacteria in $100 \%$ of cases have chronic gastritis, 10 to $20 \%$ gastric ulcers and in less than $1 \%$ have lymphoma of lymphoid tissue associated with stomach mucosa.
H. pylori can also cause gastric adenocarcinoma in 1 to $2 \%$ of infected patients (ARÉVALO et al, 2019). According to Goderska (2018) and Salih (2009) the study show that H. pylori infection is very common, especially in developing countries, suggesting that $50 \%$ of the world population is infected with this bacterium. In a meta-analysis study, carried out to estimate the worldwide prevalence of $\mathrm{H}$. pylori, a prevalence of approximately $71 \%$ was observed in Brazil (HOOL et al, 2017). The transmission of $H$. pyloriit happens orally, both from person to person, and in contaminated water and food. According to the IV Brazilian Consensus on Helicobacter pylori infection, in Brazil, inadequate living conditions, low health and socioeconomic status are risk factors for acquiring $H$. pylori infection (ARÉVALO et al, 2019). In this way, the H. pylori it manifests itself as an important risk factor for gastric cancer, emphasizing the relevance and importance of continuous studies related to this pathogenic process.

\section{MATERIALS AND METHODS}

Qualitative bibliographic review based on the analysis of published works with the objective of evaluating the relationship between the 
presence of H.pylori and the development of gastric cancer based on the elucidation of virulence, transmission, immunological response and genetic and environmental factors that participate in this process, based on Scientific articles available in the Scielo, Bireme and Ministry of Health databases. The H. pylori bacterium is a gramnegative bacillus, has a curved or spiral shape, size 0.5 to $1 \mu \mathrm{m}$ wide and 2.5 to $5 \mu \mathrm{m}$ long, has 2 to 6 flagella with $30 \mathrm{~cm}$ and $2.5 \mathrm{~nm}$ thickness.It is an infection in the stomach, causing inflammation of the gastric mucosa, such as peptic ulcers, chronic gastritis and gastric cancer. (GUIMARÃES; CORVELO; BARILE 2008). According to Guimarães, Corvelo, Barile, (2008): the H. pylori bacteria have a circular genome consisting of $1,667,867$ base pairs of DNA. It has motility, iron homeostasis, restriction and modification of DNA and has gene sequences that encode urease, flagella, vacuolinizing protein (vacA) and cytotoxin associated with gene $\mathrm{A}(\operatorname{cag} A)$, important virulence factors. The Helicobacter genus has 27 species that can be located at the bottom, body and antrum, being the latter, where bacteria are found in greater density in the stomach. The bacterium can be distributed in a focal, segmented or diffuse manner in the gastric mucosa, thus being in direct contact with the luminal membrane of the epithelial cells that line the gastric mucosa (LADEIRA et al, 2003). H. pylori can colonize only the gastric mucosa, which is rarely seen in areas of intestinal metaplasia. In the duodenal portion, the bacterium colonizes areas of gastric metaplasia. There is also a connection with gastric muciparous cells due to the neutrality of gastric mucus, which does not occur in acid mucopolysaccharides produced by goblet cells of intestinal metaplasia (FARIA etal, 2017).

\section{Virulence factors associated with H. Pylori}

VacA:According to Barbosa and Schinonni(2011), the vacuolating cytotoxin is a virulence factor that induces cell vacuolization, apoptosis, activation of positive T-CD4 lymphocytes and proliferation. This gene has two parts, if $m$. The $s$ (signaling) region has the $s 1$ and $s 2$ alleles and the $m$ (medium) region has the $m 1$ alleles, with the highest risk of damage, and $m 2$ according to Dadashzadeh et al.(2018). The VacAprotein forms channels that promote the transport of anions into the organelles, causing extreme intracellular acidification leading to hyperactivity of V-ATPase and, consequently, osmotic imbalance. The joining of the alleles sand $m$ determining the degree of cytotoxin production, directly influencing the degree of virulence of the bacterium. Strains carrying $s 1 / \mathrm{ml}$ produce a lot of cytotoxin, $s 1 / \mathrm{m} 2$ moderate toxin and $s 2 / \mathrm{m} 2$ little or no cytotoxin (BARBOSA; SCHININNI, 2010). Barbosa and Schinonni (2010) also states that in relation to apoptosis, it happens due to $p 34$ VacA, which is a subunit that is only sent to the mitochondria during apoptosis.

\section{Pathogenicity Island}

-Cag-PAI: According to Rodrigues et al (2017), strains that have cag-PAI respond in a more inflammatory manner, as they promote the production of interleukin- 8 by the host cell and the expression of the "hummingbird" phenotype, which can lead to a symptomatic picture in the form of gastric cancer, ulcer, gastritis or other manifestations. The $\operatorname{cag} A$ gene is a marker of $\operatorname{cag}-P A I$ and its strains are extremely virulent and can triple the chances of developing gastric cancer. In addition, the positive A gene can also cause the expression of interleukin 6 , being characterized as a strongly immunogenic gene and that its alterations are capable of promoting a high spectrum of inflammatory responses. (DADAHZADEH et al., 2018).

-virB11 and virD4: Located at the left end of the pathogenicity island, it is homologous to the virulence genes of the soil bacterium Agrobacterium tumefaciens, which affects plants. It can be found in patients who manifest gastritis and ulcers. Unlike the other types, the relationship between virD4 and IL-8 is still poorly understood, however, there is a consensus that it acts on the transfer of $\operatorname{cag} A$, as its non-presence modifies the action of $H$. pylori on the host according to Lemos et al., (2020).
Adherence factors: The adhesion of H. Pylori to the epithelium of the gastrointestinal mucosa is due to the adherence factors that contribute to pathogenicity, since there is an interaction between the epithelium and the bacteria that spreads its infection. Among the adherence factors, there are: $b a b A$ (blood group antigen adhesin gene), ice $A$ (indunced by contact with epithelium gene), $s a b A$ (sialic acid binding adhesin A) and oipA (outer inflammatory protein gene). $B a b A$ has three alleles, babA2 being the gene that interacts with Lewis antigens. This gene is associated with gastric adenocarcinoma (SILVA, 2013). IceA in turn has two versions iceA1, related to ulcer, and ice 2 related to gastric cancer and peptic ulcer, depending on the location where the population is studied according to Silva (2013). $S a b A$ is an adhesin that binds to sialic acid A, from $\mathrm{H}$. pylori, which when bound to the sLex antigen, which has glycoproteins with the inflammatory process. The oipA gene is located on the H. pylori chromosome. The presence of this functional gene is related to an increase in interleukin- 8 associated with gastric cancer (RODRIGUES et al., 2017).

Streaming: The form of transmission of H.pylori remains controversial, but it is unanimous that this agent only reaches the gastric mucosa through the mouth, mainly because of its non-invasive nature. Because of this, the hypotheses of oral-oral and fecal-oral transmission are the most universally accepted; a third way, however, has recently appeared as possible, called iatrogenic or gastro-gastric (KOIDAIRA etal, 2002; TEIXEIRA et al, 2016). The hypothesis of oral-oral transmission is strongly supported by several studies that demonstrated the presence of H.pylori in the oral cavity, detected through culture and PCR of saliva and dental plaque (GUIMARÃES etal, 2008). Likewise, other trials have observed the presence of this agent in the gastric juice of infected patients, making the role of vomiting and gastroesophageal reflux prominent as mechanisms of mouth infection (LADEIRA, SALVADORI; RODRIGUES, 2003; VIEIRA, 2017). In turn, fecal-oral transmission is supported by several other studies that pointed out the presence of this bacterium in the feces of children and adults infected around the world. In addition, many other studies have emphasized the high prevalence of contamination in developing populations, very crowded and without adequate water treatment and who consume raw foods. Despite these findings, the exact mechanism of transmission by this means and its epidemiological importance remain unclear (BARBOSA; SCHINONNI, 2011; MENEZES etal, 2015). In a more current scenario, a third alternative of infection arises, the iatrogenic or gastro-gastric one resulting from the use of improperly sterilized endoscopic tubes, which act as vehicles for transmitting the bacteria from infected people to other healthy ones (GUIMARÃES, CORVELO, BARILE, 2008; TEIXEIRA, 2016).

\section{Factors that influence gastric cancer}

Brief definition of Gastric Cancer (GC): Gastric Cancer or Stomach Cancer is the end product of a series of cellular and genetic mutations that probably start in childhood associated with environmental and dietary factors. GC cases occur $90 \%$ somewhere in the stomach lining, appearing as an elevated, irregular lesion (tumor), from millimeters to centimeters in diameter, often ulcerated and may resemble a mole with a small crater at its highest point. Ulceration is the result of uncontrolled cell multiplication, characteristic of malignancy. (BRASILEIRO FILHO, Geraldo, 2016)

Causes of its occurrence : Gastric cancer (GC) remains one of the most important neoplasms worldwide, with significant incidence and mortality, but its cause remains controversial, and several factors have been implicated in its process of carcinogenesis. It is observed that some risk factors increase the chance of stomach cancer occurring. Among these factors, genetic, environmental and dietary characteristics are relevant - aspects of the person, his habits and his environment, which alone would not be able to cause the disease. (MARTINS, 2016). Helicobacter pylori (Hp) has also been implicated in the carcinogenesis of gastric cancer. This association has been suggested by the observation of higher rates of Hp infection in patients with gastric cancer, when compared to normal controls in 
Western countries. On the other hand, in countries with a high incidence of neoplasia, the prevalence of Hp infection appears to be even higher, occurring at an early age in the general population (BRESCIANI; LATIF; COSER; YAGI etal, 2011). The influence of $\mathrm{Hp}$ infection in relation to gastric carcinogenesis is attributed to the production of specific cytokines and enzymes that cause chronic atrophic gastritis and intestinal metaplasia. However, this occurrence is not uncontroversial, as there are studies that associate Hp only with chronic gastritis infection and exclude this association for gastric cancer. On the other hand, it is possible that countries with a low incidence of gastric cancer have high rates of $\mathrm{Hp}$ infection (BRESCIANI; LATIF; COSER; YAGI etal, 2011).

Other studies point to a close relationship between Helicobacterpylori and gastric cancer, indicating that the carcinogenic process, in these cases, develops over several years, initially manifesting itself as chronic gastritis, gastric atrophy, intestinal metaplasia, dysplasia and, finally, invasive cancer (QUINTAIROS; SÁ; SOUSA; FRAZÃO etal, 2020). In addition, the World Health Organization recognizes Helicobacterpylori as a group I carcinogen due to the causal relationship demonstrated between this bacterium and the development of gastric cancer (QUINTAIROS; SÁ; SOUSA; FRAZÃO etal, 2020). Gastric adenocarcinoma (GA) is a multifactorial disease that results from the interaction of environmental factors and the individual. He identifies the former as the most important, as they include infection by H. pylori and components of the diet. It also mentions genetic factors (factors related to the host) - which are constitutional - and precancerous conditions or lesions, which in turn can also be related to environmental factors"(BRASILEIRO FILHO, 2016). Among the environmental factors, the diet stands out. Eating habits are important because potentially harmful foods and compounds remain in the stomach lumen in contact with the mucosa for a considerable time. Consumption of salty foods, or foods and beverages containing potentially mutagenic compounds, such as nitrates (food preservatives and drinks derived from malt), benzopyrene and derivatives (smoked foods) and tannins (red wine), and / or deficient in antioxidant compounds (vitamins $\mathrm{C}$ and $\mathrm{E}$ ) - these found mainly in fresh fruits and vegetables - are related to a higher degree of risk. Excess salt is a component that irritates the gastric mucosa and, therefore, is associated with chronic gastritis, which in the long term evolves in degeneration of the mucosa until it reaches the intestinal metaplasia. Chronic atrophic gastritis is considered a precancerous condition, being more commonly found in populations at higher risk for GA.

Thus, the situation of gastric atrophy leads to a decrease in the production of hydrochloric acid in the stomach (hypochlorhydria) or the absence of hydrochloric acid production by the stomach (achlorhydria), which causes the stomach $\mathrm{Ph}$ to become higher, enabling the growth of bacteria capable of converting nitrates from the diet into nitrites, which, in combination with amines (also from the diet, form nitrosamines. Vitamins $\mathrm{C}$ and $\mathrm{E}$ (potent antioxidants) come into play which inhibit the transformation of nitrates into nitrites - these vitamins can be produced in the gastric mucosa (ascorbic acid) or ingested with food. The result of increased production of nitrites and nitrosamines, the deficiency of antioxidants or the presence of other carcinogenic compounds in the gastric lumen, allow DNA damage to appear both in the gastric mucosa without lesions and in the epithelium with intestinal metaplasia. (BRASILEIRO FILHO, 2016). Intrinsically linked to the diet are the socioeconomic conditions whose improvement allows the use of the refrigerator and more improved ways of preserving and storing food and, on the other hand, the daily consumption of milk, fruits and vegetables rich in vitamin $\mathrm{C}$ are decisive for reducing cases of malignant tumors of the stomach. (MARTINS, 2016). In groups of low socioeconomic status, the incidence of gastric cancer and the mortality rate are three times higher than in populations of high socioeconomic status, representing a public health problem in developing countries. (QUINTAIROS; SÁ; SOUSA; FRAZÃO etal, 2020).
The National Cancer Institute (INCA) establishes a list of factors that increase the risk of stomach cancer:

- Overweight and obesity

- Alcohol consumption

- Excessive consumption of salt, foods salted or preserved in salt

- $\quad$ Smoking

- Water intake from wells with a high nitrate concentration

- Pre-existing diseases, such as pernicious anemia, precancerous lesions (such as atrophic gastritis and intestinal metaplasia) and infections by the bacterium Helicobacter pylori (H. pylori)

- Combination of smoking with alcoholic beverages or with previous stomach surgery

- Occupational exposure to ionizing radiation, such as X-rays and gamma rays, in industries or medical institutions

- Exposure of rural workers to a series of chemical compounds, in particular pesticides

- Occupational exposure, in rubber production, to various chemical compounds, many classified as known to be carcinogenic, such as benzene, mineral oils, coal tar products, zinc compounds and a series of pigments

- Having first-degree relatives with stomach cancer.

\section{RESULTS}

Gastric cancer phases, diagnosis and treatment: Gastric pathologies have a fair correlation to $H$. pylori infection, and as they progress, they can result in gastric cancer. Infection with $\mathrm{H}$. pylori associated with the diet are preponderant factors to cause neoplasia in the distal part of the stomach (antro-pyloric and pyloric regions), whereas gastroesophageal reflux disease and obesity are related to the etiology of neoplasia of the proximal part of the stomach (DE SOUZA, 2021). The predominant histology in gastric neoplasms is subdivided into adenocarcinomas, which are the most prevalent, with more than $90 \%$ of cases; lymphomas, with $3 \%$ of cases and the most common of these is non-Hodgkin; and sarcomas, these malignant tumors being rare in only $2 \%$ of cases (GOMES; BRISOTTI, 2020). Adenocarcinomas, being in their entirety the type most responsible for gastric cancer, can be histologically subdivided into intestinal, in which it is related to atrophic gastritis and intestinal metaplasia; diffuse, which is triggered by pangastritis without atrophy (GOMES, 2020). When taking to the macroscopic aspect, there is the Borrmann classification, which divides into four groups: type I - lesions that project into gastric lumen, such as polypoid, exophytic, papillary or vegetating; type II - ulcerated neoplasms measuring more than $3 \mathrm{~cm}$ in diameter, limited and without infiltration to neighboring tissues; III - ulcerated and infiltrated cancer; and type IV - diffuse infiltration of a specific segment of the gastric wall or of the whole, with the possibility of ulcerations of varying depth (ZATERKA; EISIG, 2011). Because it grows insidiously, and is mostly asymptomatic, gastric adenocarcinoma to be detected at an early stage of the disease is only possible through screening (DE LIMA NETO, 2019). Early diagnosis is extremely important and favors the reduction of the stage of presentation of the neoplasia, and this occurs through the approach of individuals with initial signs / symptoms of the disease. The screening, on the other hand, has no scientific evidence that brings more benefits than risks, and so far, is not indicated (INCA, 2021). The diagnosis is based, for the most part, on upper gastrointestinal endoscopy (EDA) with biopsies of suspicious lesions, with the sensitivity of this procedure greater than $97 \%$. In addition, tumor markers, such as carcinoembryonic antigen (CEA), can also be used, which help in diagnosis because it is an indicator of malignancy. In advanced cases, laboratory tests can indicate anemia, presence of occult blood in the stools, hypoproteinemia and changes in liver function tests (ZATERKA; EISIG, 2016). Other tests that contribute to gastric tumor staging are abdominal magnetic resonance imaging, computed tomography of the abdomen, PET-SCAN and abdominal ultrasound (INCA, 2021). 
The prognosis and treatment are defined according to the location and staging of the tumor, as well as the number of lymph nodes that are resected and affected. As most of them are asymptomatic, more than $40 \%$ of diagnosed cases are at an advanced stage. In turn, when diagnosed at an early stage, more than $45 \%$ of cases can be cured when fully resected (COELHOetal, 2019). When early, limited to the mucosa and submucosa, the option of endoscopic resection is viable, with lesions below $2 \mathrm{~cm}$, well differentiated, restricted to the mucosa, not ulcerated and without angiolymphatic invasion. What is desirable in the procedure is that it be removed in monoblock, with free macroscopic margins and fixed for pathological analysis. Surgery should, whenever possible, resect the entire extension of the neoplasia (even in the T4-tumor stage invading the serosa or adjacent structures). Other options include gastrectomy with lymphadenectomy. Advanced lesions, on the other hand, are already treated through gastrectomy with adjuvant therapy such as chemotherapy and, when necessary, radiotherapy as well (INCA, 2021). Regarding the treatment of $H$. pylori in the patient diagnosed with gastric cancer, this is indicated mainly in cases of MALT lymphoma, as it has evidence of tumor improvement with antibiotic therapy (GOMES, 2020). However, in cases of adenocarcinoma the treatment of the bacterium can also help to have a good prognosis, even if gastric carcinogenesis cannot be explained only with the infection of this pathogen. Therefore, the conduct will always be individualized for each patient, estimating the risks and benefits of each procedure and the staging of gastric cancer.

\section{CONCLUSION}

The correlation between the pathogenicity of the bacterium is notorious $H$. pyloriwith the development of neoplastic phenomena, especially gastric cancer. This aspect is corroborated by the fact that it is a pathogen with a wide population distribution, maximum in underdeveloped countries like Brazil, since sanitary conditions and socioeconomic indexes catalyze its action, allowing a variety of scientific studies about its long-term consequences. Although most individuals are asymptomatic, the inflammatory process generated by the immune system to the microorganism in question can culminate in the development of etiologically diverse tumors, namely, in an increasing order of prevalence: adenocarcinomas, MALT lymphomas and sarcomas. In this scenario, it is essential to diagnose gastric cancer by means of Upper Digestive Endoscopy (EGD) with biopsies of lesions, tumor markers (CEA) and complementary laboratory tests. Magnetic resonance imaging of the abdomen, despite the high cost and low accessibility, can be used, as well as PET-SCAN tomography and ultrasound of the abdomen. In addition, the prognosis and treatment will depend on the results of such diagnostic methods, which elucidate the location and staging of the tumor. It is of utmost importance to eradicate the bacteria H.pyloritogether with the agent's cure control, especially when there is a clinical history of pre-existing pathologies such as for example; intense histological gastritis, MALT lymphoma, gastric adenocarcinoma and healed peptic ulcer. Treatment should be done with Amoxicillin $1 \mathrm{~g}$ every 12 hours, Clarithromycin 500mg every 12 hours and Proton Pump Inhibitor, for 14 days, according to the IV Brazilian Consensus of H.pilory. If the patient is allergic to these drugs, second-line therapy can be offered. The cure control is part of the treatment to confirm whether there was suppression of the bacterium or therapeutic failure, thus preventing recurrences, evolution to gastric, duodenal ulcers, MALT lymphoma and assessment of whether there is microbial resistance with the administered antimicrobials. In addition, the control reveals whether the treatment should be continued or not, thus improving the patient's quality of life, since the therapy is unique, patient compliance is fundamental. In this aforementioned context, the IV Consensus recommends that $\mathrm{H}$. Pylori's research done by histopathological examination, considered the gold standard and be carried out with at least 2 biopsies of 2 antrum fragments and 2 body fragments. However, there is a need to eliminate the bacterium in question, which is a carcinogen that is harmful to the gastric mucosa. Thus, there is the primacy of carrying out the treatment as early as possible and guiding the patient regarding his / her life habits, such as, for example, smoking cessation, in which the incidence of gastric cancer is double when compared to non-smokers, in addition to basic sanitary notions.

\section{REFERENCES}

ABBAS, A.K.; LICHTMAN, A.H.; PILLAI, S. Imunologia Celular e Molecular. 8a Edição. Elsevier, pag. 705. 2015.

ARÉVAlO, A.; OTERO, W. A.; TRESPALACIOS, A. A. Helicobacterpylori: resistenciamúltipleen pacientes de BogotáColombia. Biomédica, v. 39, 2019.

BARBOSA, Joel Antonio; SCHINONNI, Maria Isabel. Helicobacterpylori: Associação com o câncer gástrico e novas descobertas sobre os fatores de virulência. Revista de Ciências Médicas e Biológicas, v. 10, n. 3, p. 254-262, 2011.

BRASILEIRO FILHO, Geraldo. Bogliolo, patologia. 9. ed., Rio de Janeiro: Guanabara Koogan, p.1019-1020, 2016.

BRESCIANI, Claudio; LATIF, Ibrahim; COSER, Roger Beltrati; YAGI, Osmar; DEUTSCH, Claudio Roberto; MUCERINO, Donato; ZILBERSTEIN, Bruno; CECCONELLO, Ivan. Determinação histopatológica da presença do helicobacterpylori em câncer gástrico. 2011.

COELHO, Julita Maria Freitas et al. Adenocarcinoma gástrico em uma unidade de alta complexidade em oncologia. Revista de Saúde Coletiva da UEFS, v. 9, p. 33-38, 2019.

DADASHZADEH, K.; PEPPELENBOSCH, M. P.; ADAMU, A.I. HelicobacterpyloriPathogenicityFactorsRelatedtoGastricCancer. CanadianJournalofGastroenterologyand Hepatology, v. 2017, n. 7942489, p. 1-6, 2018.

DE LIMA NETO, João Batista et al. CÂNCER GÁSTRICO E HELICOBACTER PYLORI: RELAÇÃO ENTRE INFECÇÃO E OCORRÊNCIA. Mostra Científica em Biomedicina, v. 4, n. 1, 2019.

DE SOUZA, Daniela Heitzmann Amaral Valentim et al. Helicobacterpylori como principal fator de risco para adenocarcinoma gástrico. BrazilianJournalof Health Review, v. 4, n. 2, p. 4149-4158, 2021.

FARIA, G. E.; SALVI, K.; CORTÊS, P. P. R.; PASSOS, M. A. T.; Ferraz, A. R. H. Pylori e câncer gástrico - Revisão de literatura. Revista De Saúde, 8(1 S1), 88. Rio de Janeiro, 2017.

GODERSKA $\mathrm{K}$, Agudo Pena $\mathrm{S}$, Alarcon $\mathrm{T}$. Helicobacterpyloritreatment: antibioticsorprobiotics. Appl Microbiol Biotechnol. 102:1-7. 2018.

GOMES, Camila Moreira; BRISOTTI, Joao Luiz. Correlação entre infecção por Helicobacterpylori e neoplasia gástrica: estudo retrospectivo. Manuscripta Médica, v. 3, p. 21-30, 2020.

GUIMARÃES, J.; CORVELO, T. C.; BARILE, K. A. Helicobacterpylori: fatores relacionados à sua patogênese. Rev. Para. Med. v.22 n.1 Belém mar. 2008.

HOOI JKY, Lai WY, Ng WK, Suen MMY, Underwood FE, Tanyingoh D, et al. Global Prevalence of Helicobacter pylori Infection: Systematic Review and Meta-Analysis. Gastroenterology. 153:420-9. 2017.

INCA. Instituto Nacional do Câncer. Câncer de Estômago. 2021. Disponível em: https://www.inca.gov.br/tipos-de-cancer/cancerde-estomago. Acesso em: 24/03/2021

JIMÉNEZ, Geiner. Helicobacterpylori como patogeno emergente enel ser humano. Rev. costarric. salud pública, v. 27, n. 1, p. 65$78,2018$.

KODAIRA, M.S.; ESCOBAR, A.M.U.; GRISI, S. Aspectos epidemiológicos do Helicobacterpylori na infância e adolescência. São Paulo, v. 36, n. 3, p. 356-369, 2002.

LADEIRA, M. S. P.; SALVADORI, D. M. F.; RODRIGUES, M. A. M.; Biopatologia do Helicobacterpylori. Rio de Janeiro, v. 39, n. 4, p. 335-342, 2003.

LEMOS, Joice Ribeiro et al. Genes de virulência e polimorfismos gênicos ligados à suscetibilidade à infecção por Helicobacterpylori. Saúde em Revista, v. 20, n. 52, p. 119-130.

LIMA, Valeska Portela; RABENHORST, Silvia Helena Barem. Genes associados à virulência de Helicobacterpylori. 2009. 
MARTINS, Daniela Maria Rocha.Helicobacterpylori e o cancro gástrico. 2016.

MENEZES, G.L. et al. Aplicação da biologia molecular no diagnóstico de Helicobacterpylori: revisão de literatura. Rev. Saúde e Educação do Instituto de Ciência e Saúde. Goiânia, v. 1, n. 1, p. 132-140, 2015.

QUINTAIROS, Midiã Quaresma; SÁ, Lorenna Luciano; SOUSA, Gisele Medeiros de; FRAZÃO, Humberto Augusto de Abreu; BRITO, Ana Paula Santos Oliveira; GARCIA, Hamilton Cesar Rocha. Doenças relacionadas à infecção pelo Helicobacterpylori: revisão sistemática. 2020

RODRIGUES JA, et al. Genes de virulência em Helicobacterpylori: componentes estruturais e métodos de detecção.

SAÚDE \& CIÊNCIA EM AÇÃO - Revista Acadêmica do Instituto de Ciências da Saúde, 2017; 3(2): 10-22.
SALIH BA. Helicobacter pylori Infection in Developing Countries: The Burden for How Long? Saudi J Gastroenterol. 15:201-7. 2009.

SILVA, Cícero Igor Simões Moura. Estudo de marcadores de virulência do Helicobacterpylori e sua associação com gastrite, úlcera péptica e câncer gástrico no nordeste do Brasil. 2013.

TEIXEIRA, T.M.; SOUZA, I.K.F., ROCHA, R.D.R. Helicobacterpylori: infecção, diagnóstico laboratorial e tratamento. Rev. Percurso Acadêmico. Belo Horizonte, v.6, n. 12, p. 1-11, 2016.

VIEIRA, B.M.A., NUNES, C.P. H. Pylori versus úlcera gástrica nas EDA do HCTCO. Rev. Faculdade de Medicina de Teresópolis. Rio de Janeiro, v. 1, n.1, p. 97-108, 2017.

ZATERKA, Schlioma; EISIG, Jaime N. Tratado de gastroenterologia: da graduação à pós-graduação. $2^{\mathrm{a}}$ edição. São Paulo: Atheneu, FBG, 2016. 653 p. 